\title{
Hsp90 facilitates accurate loading of precursor piRNAs into PIWI proteins
}

\author{
NATSUKO IZUMI, ${ }^{1,4}$ SHINPEI KAWAOKA,${ }^{2,4,5}$ SATOSHI YASUHARA, ${ }^{2}$ YUTAKA SUZUKI, $^{3}$ SUMIO SUGANO, ${ }^{3}$ \\ SUSUMU KATSUMA, ${ }^{2,6}$ and YUKIHIDE TOMARI ${ }^{1,3,6}$ \\ ${ }^{1}$ Institute of Molecular and Cellular Biosciences, The University of Tokyo, 1-1-1 Yayoi, Bunkyo-ku, Tokyo 113-0032, Japan \\ ${ }^{2}$ Department of Agricultural and Environmental Biology, Graduate School of Agricultural and Life Sciences, The University of Tokyo, 1-1-1 Yayoi, \\ Bunkyo-ku, Tokyo 113-8657, Japan \\ ${ }^{3}$ Department of Medical Genome Sciences, Graduate School of Frontier Sciences, The University of Tokyo, 4-6-1 Shirokanedai, Minato-ku, Tokyo \\ 108-8639, Japan
}

\begin{abstract}
PIWI-interacting RNAs (piRNAs) defend the genome against transposon activity in animal gonads. The Hsp90 chaperone machinery has been implicated in the piRNA pathway, but its exact role remains obscure. Here, we examined the effect of 17$\mathrm{N}$-allylamino-17-demethoxygeldanamycin (17-AAG), an Hsp90-specific inhibitor, on the piRNA pathway. In the silkworm ovary-derived BmN4 cells, 17-AAG treatment reduced the level of piRNAs and PIWI proteins. In vitro, the $5^{\prime}$-nucleotide preference upon precursor piRNA loading was compromised by $17-\mathrm{AAG}$, whereas 3 '-end trimming and 2'-O-methylation were unaffected. Our data highlight a role of Hsp90 in accurate loading of precursor piRNAs into PIWI proteins.
\end{abstract}

Keywords: chaperone; Hsp90; PIWI; PIWI-interacting RNAs; piRNAs

\section{INTRODUCTION}

PIWI proteins bind to 23-30 nucleotides (nt)-long small RNAs called PIWI-interacting RNAs (piRNAs) to form the RNA-induced silencing complex (RISC) (Klattenhoff and Theurkauf 2008; Ghildiyal and Zamore 2009; Malone and Hannon 2009). piRNA-RISC plays an important role in silencing transposable elements in animal gonads. Indeed, in many organisms, mutations in PIWI genes result in de-silencing of transposons, causing defects in germline development.

Unlike small interfering RNAs (siRNAs) and microRNAs (miRNAs), piRNAs are born single stranded in a Dicer-independent manner (Vagin et al. 2006; Houwing et al. 2007). In the current model for piRNA-RISC formation, single-stranded primary transcripts are first produced from piRNA-generating loci. Then, these transcripts are likely fragmented into precursor piRNAs (pre-piRNAs) that are longer than mature piRNAs, through multiple steps including endonucleolytic cleavage by Zucchini (Brennecke et al. 2007; Klattenhoff et al. 2009; Ipsaro et al. 2012; Kawaoka et al. 2012; Muerdter et al. 2012; Nishimasu et al. 2012). A subset of PIWI proteins

\footnotetext{
${ }^{4}$ These authors contributed equally to this work.

${ }^{5}$ Present address: Cold Spring Harbor Laboratory, Cold Spring Harbor, NY 11724, USA

${ }^{6}$ Corresponding authors

E-mail tomari@iam.u-tokyo.ac.jp

E-mail katsuma@ss.ab.a.u-tokyo.ac.jp

Article published online ahead of print. Article and publication date are at http://www.rnajournal.org/cgi/doi/10.1261/rna.037200.112.
}

(e.g., Siwi in the silkworm) preferentially binds to pre-piRNAs with 5' U (1U) (Brennecke et al. 2007; Gunawardane et al. 2007; Kawaoka et al. 2009). After PIWI loading, 3' ends of pre-piRNAs are trimmed by an enzyme named Trimmer to the mature piRNA length (Kawaoka et al. 2011). Trimmer is biochemically characterized as a $\mathrm{Mg}^{2+}$-dependent $3^{\prime}$-to-5' exonuclease, but its identity remains unknown. Finally, coupled with trimming, $3^{\prime}$ ends are $2^{\prime}$-O-methylated by Hen 1 (Horwich et al. 2007; Kirino and Mourelatos 2007; Ohara et al. 2007; Saito et al. 2007; Kawaoka et al. 2011), generating mature RISC containing primary $1 \mathrm{U}$ piRNAs. This is called the primary processing pathway. Via RISC, primary piRNAs cleave their complementary target RNAs across from positions 10 and 11 . The $3^{\prime}$ fragments of the cleavage products are then incorporated into another subset of PIWI proteins (e.g., BmAgo3 in the silkworm), and their $3^{\prime}$ ends are likely trimmed to generate secondary piRNAs, which often have adenine at position 10 (10A) (Brennecke et al. 2007; Gunawardane et al. 2007; Kawaoka et al. 2009, 2011). Such a cleavage-dependent piRNA biogenesis is called the pingpong amplification loop or secondary processing pathway (Brennecke et al. 2007; Gunawardane et al. 2007). In insects, $1 \mathrm{U}$ primary piRNAs are often antisense to transposons, and 10A secondary piRNAs are sense to transposons, but some transposon-derived piRNAs show opposite strand polarity. In theory, 10A secondary piRNAs can further direct production of $1 \mathrm{U}$ secondary piRNAs, although they are indistinguishable from $1 \mathrm{U}$ primary piRNAs. 
Recent reports have implicated Heat shock protein 90 (Hsp90) and its cochaperones in the piRNA pathway (Specchia et al. 2010; Gangaraju et al. 2011; Olivieri et al. 2012; Preall et al. 2012; Xiol et al. 2012). In flies, disruption of Hsp90 causes reduction of a subset of piRNAs and de-silencing of a number of transposons (Specchia et al. 2010). Hsp90 interacts with Piwi, one of the three fly PIWI proteins, and regulates the phosphorylation level of Piwi without affecting its protein stability (Gangaraju et al. 2011). Moreover, an Hsp90 cochaperone, Shutdown, plays a critical role in both primary and secondary piRNA biogenesis in flies (Olivieri et al. 2012; Preall et al. 2012), while Fkbp6, a mouse ortholog of Shutdown, is exclusively required for secondary piRNA biogenesis (Xiol et al. 2012). In the silkworm ovary-derived cell line BmN4, inhibition of Hsp90 causes accumulation of 16-nt RNAs in BmAgo3 (but not in Siwi), which presumably correspond to the $5^{\prime}$ fragments of Siwi-directed cleavage products (Xiol et al. 2012). Given these diverse observations, the exact role of Hsp90 in the piRNA pathway still remains obscure.

In this study, we investigated the role of Hsp90 in the piRNA pathway using BmN4 cells and a BmN4-cell-derived in vitro system that recapitulates a part of the primary piRNA biogenesis (Kawaoka et al. 2011). Our data highlight a role of Hsp90 in accurate loading of prepiRNAs into PIWI proteins.

\section{RESULTS AND DISCUSSION}

\section{Inhibition of Hsp90 reduces the two PIWI proteins in vivo}

To investigate the role of Hsp90 in piRNA biogenesis, we first sought to deplete Hsp90 in BmN4 cells by RNAi. However, the knockdown efficiency was extremely low (data not shown), and we decided to inhibit the Hsp90 activity by 17-allylamino-17-demethoxygeldanamycin (17-AAG), a specific Hsp90 antagonist (Kamal et al. 2003). We treated BmN4 cells with 17-AAG (dissolved in DMSO) for $48 \mathrm{~h}$. In this condition, cell viability was comparable to that of the cells treated by DMSO only (Supplemental Fig. S1). As previously reported (Xiol et al. 2012), 17-AAG treatment induced de-silencing of a number of transposons, especially Pao (Supplemental Fig. S2). Moreover, protein levels of both silkworm PIWI proteins, Siwi and BmAgo3, were severely decreased by $17-A A G$ treatment (Fig. 1A). Reduction of the PIWI proteins was recapitulated by using cells stably expressing Flag-Siwi or Flag-BmAgo3 (Fig. 1A). In contrast, quantitative PCR (qPCR) analysis revealed that 17-AAG treatment did not alter the steady-state mRNA levels of these two genes (Fig. 1B). Thus, the reduction of Siwi and BmAgo3 occurred at the protein level.

\section{Inhibition of Hsp90 reduces piRNAs in vivo}

To determine if 17-AAG treatment affects piRNA population, we analyzed RNAs from BmN4 cells treated with 17-AAG or DMSO. The overall piRNA level, simply visualized by SYBR Gold staining, was reduced by 17-AAG (Supplemental Fig. S3). We then immunoprecipitated Siwi and BmAgo3 and visualized the bound RNAs by radiolabeling (Fig. 1C,D). As reported previously (Xiol et al. 2012), 16-nt RNA population was detected in the BmAgo3-immunoprecipitates upon
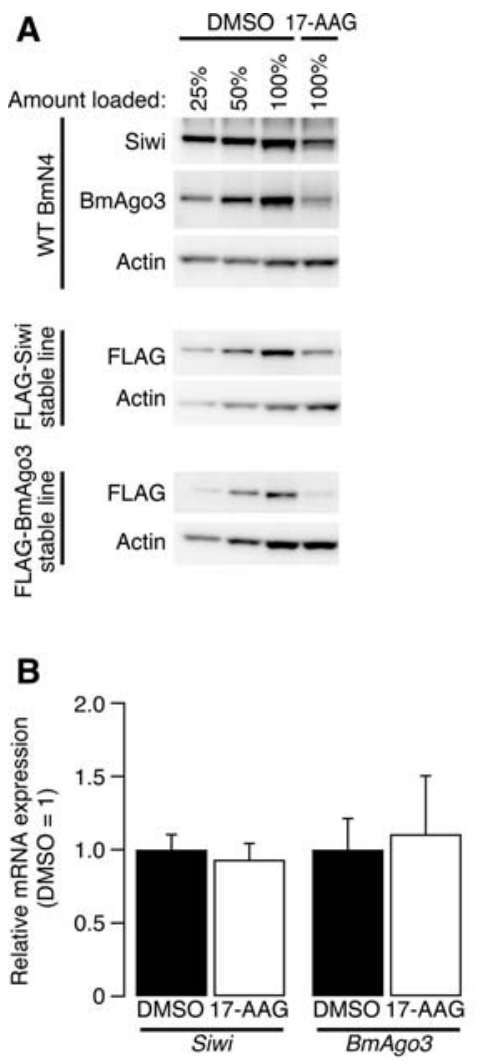
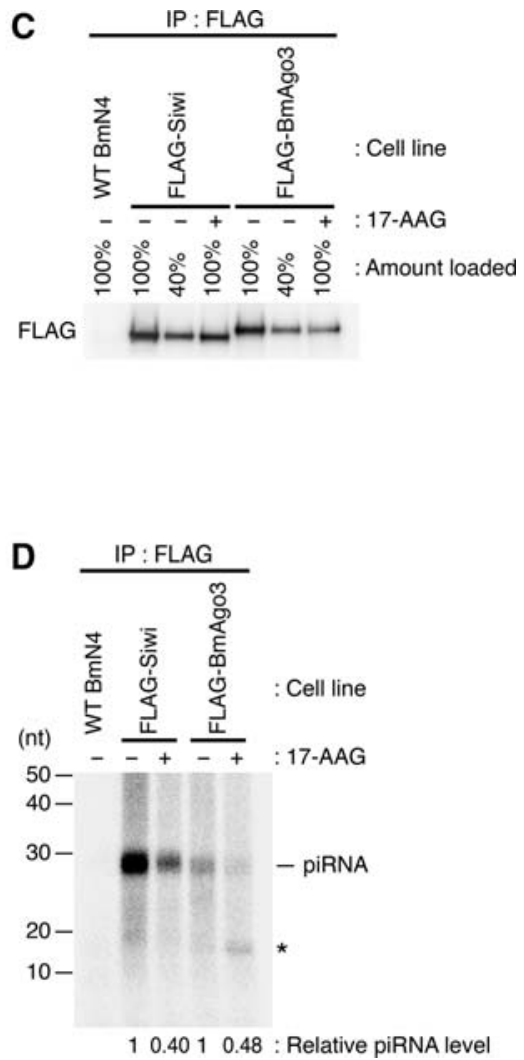

FIGURE 1. Inhibition of Hsp90 reduces Siwi and BmAgo3 proteins in vivo. (A) Wild-type (WT) BmN4 cells, Flag-Siwi-expressing cells, and Flag-BmAgo3 expressing cells were treated with DMSO or $10 \mu \mathrm{M}$ 17-AAG for $48 \mathrm{~h}$. Total cell lysates were subjected to Western blot analysis with anti-Siwi, anti-BmAgo3, anti-Flag, and anti-Actin antibodies. Actin served as a loading control. (B) The levels of Siwi and BmAgo3 mRNAs in the BmN4 cells treated with DMSO or $10 \mu \mathrm{M}$ 17-AAG for $48 \mathrm{~h}$ were measured by qPCR. rp49 served as an internal control. The average \pm standard deviations from three independent trials are shown. $(C, D)$ Wild-type (WT) BmN4 cells, Flag-Siwi, or FlagBmAgo3 stably expressing cells were treated with DMSO or $10 \mu \mathrm{M} 17-\mathrm{AAG}$ for $48 \mathrm{~h}$. The cell lysates were subjected to immunoprecipitation with anti-Flag antibodies and analyzed by Western blot (C). RNAs bound to Flag-Siwi or Flag-BmAgo3 were purified from the immunoprecipitates and detected by the $3^{\prime}$-end radiolabeling with $\left[a^{32} \mathrm{P}\right]$ cordycepin $5^{\prime}$-triphosphate $(D)$. Siwi- and BmAgo3-bound piRNAs were reduced in proportion to the reduction of the Piwi proteins. ${ }^{*}$ ) An 16-nt short RNA accumulation in BmAgo3 immunoprecipitates in the presence of 17-AAG. 
17-AAG treatment (Fig. 1D). In addition, we observed a reduction of Siwi- and BmAgo3-bound piRNAs to a degree consistent with the decrease of these proteins by 17-AAG (Fig. 1C,D). To further analyze how Hsp90 inhibition affects the piRNA abundance and composition, we carried out deep sequencing of total small RNAs and Siwi- and BmAgo3-bound piRNAs with or without 17-AAG treatment (Supplemental Table 1). In the silkworm piRNA pathway, Siwi preferentially incorporates $1 \mathrm{U}$ piRNAs, while BmAgo3 does not show a $5^{\prime}$-nucleotide preference (Kawaoka et al. 2009, 2011). Instead, BmAgo3-bound secondary piRNAs are enriched for 10A. For simplicity, our analyses excluded piRNAs with both $1 \mathrm{U}$ and $10 \mathrm{~A}$, thereby focusing on " $1 \mathrm{U}$ (but not $10 \mathrm{~A})$ " and "10A (but not 1U)" piRNAs that matched the silkworm genome. When normalized to $5 \mathrm{~S}$ ribosomal RNA fragments (see Materials and Methods), 17-AAG treatment decreased $1 \mathrm{U}$ piRNAs by $\sim 60 \%$ and $10 \mathrm{~A}$ piRNAs by $\sim 40 \%$ in their abundance in the total small RNA library (Fig. 2A), agreeing with the reduction of Siwi- and BmAgo3-bound piRNAs on the gel (Fig. 1D). On the other hand, sequencing analysis of Siwi- and BmAgo3bound piRNAs showed no substantial change in the overall $1 \mathrm{U} / 10 \mathrm{~A}$ nucleotide composition by 17-AAG treatment (Fig. 2B). Classification of Siwi- and BmAgo3-bound piRNAs by individual transposons from which they derived also exhibited little overall change in their ratio between $1 \mathrm{U}$ and 10A piRNAs (Fig. $2 \mathrm{C}$ ), although $\sim 35 \%$ of Siwi-bound transposon piRNAs and $\sim 48 \%$ of Ago3-bound transposon piRNAs pointed to a slight but significant $(P<0.01$ by Fisher's exact test) loosening of their specific nucleotide preferences (Fig. 2C). The length distribution of Siwi-bound piRNAs (27-28 nt) and BmAgo3-bound piRNAs (26-27 nt) was also unaffected by 17-AAG (Fig. 2D). However, in the total piRNA pool, the peak of the length distribution showed a shift from $28 \mathrm{nt}$ to $27 \mathrm{nt}$ by the 17-AAG treatment (Fig. 2E). These results together suggest that both Siwi- and BmAgo3-bound piRNAs were reduced by Hsp90 inhibition with little change in their compositions, and the reduction was more pronounced for Siwi-bound piRNAs.
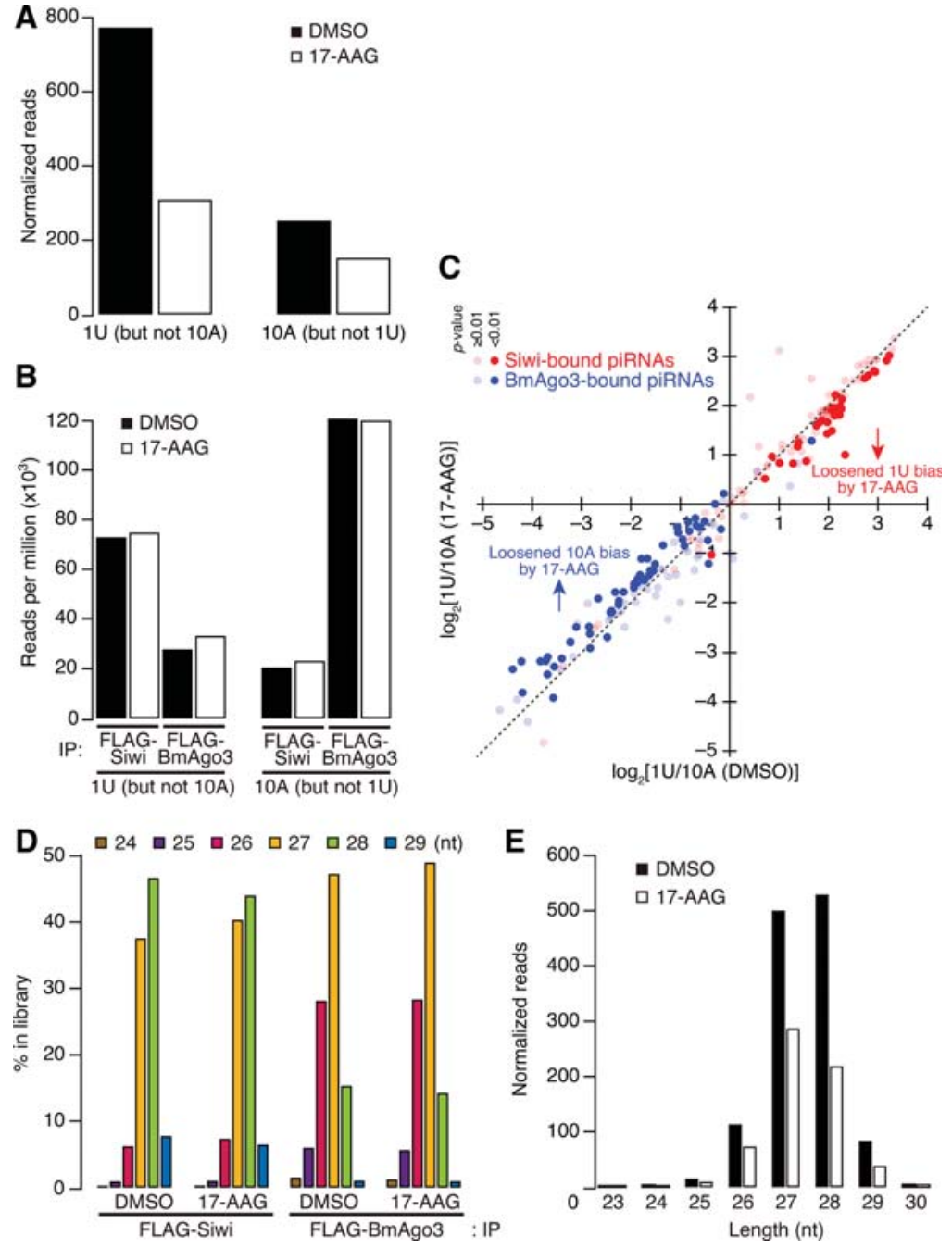

FIGURE 2. Inhibition of Hsp90 reduces Siwi- and BmAgo3-bound piRNAs in vivo. $(A)$ Abundance of $1 \mathrm{U}$ (but not 10A) and 10A (but not 1U) piRNAs in the total small RNA library with DMSO or 17-AAG treatment. Reads were normalized to 5 S ribosomal RNA fragments. 1U piRNAs and 10A piRNAs were reduced by $\sim 60 \%$ and $\sim 40 \%$, respectively, by $17-A A G$. $(B)$ The 1U/10A composition of Siwi- and BmAgo3-bound piRNAs was essentially unaffected by 17-AAG treatment. $(C)$ Comparison of the $1 \mathrm{U} / 10 \mathrm{~A}$ ratio of piRNAs for each transposon with DMSO $(x-$ axis) or 17-AAG treatment ( $y$-axis). (Red circles) Siwi- and (blue circles) BmAgo3-bound piRNAs; the color density reflects the $P$-value of a Fisher's exact test for $2 \times 2$ contingency tables consisting of the numbers of $1 \mathrm{U}$ and $10 \mathrm{~A}$ piRNA reads under DMSO and 17-AAG treatment conditions. The change was small overall, but statistically significant changes of individual transposonderived piRNAs pointed to loosening of the specific $1 \mathrm{U}$ and 10A biases of Siwi- and BmAgo3-bound piRNAs, respectively. $(D)$ The length distribution of Siwi-bound piRNAs (27-28 nt) and BmAgo3bound piRNAs (26-27 nt) was essentially unaffected by 17-AAG. (E) Length distribution and the abundance of piRNAs in the total small RNA library with DMSO or 17-AAG treatment. Reads were normalized to $5 \mathrm{~S}$ ribosomal RNA fragments. The shift in the length distribution indicates that the reduction of Siwi-bound piRNAs was more pronounced than BmAgo3-bound piRNAs.

\section{Hsp90 facilitates accurate pre-piRNA loading in vitro}

A previous study demonstrated that unloaded, RNA-free Argonaute2 (Ago2) is destabilized in the absence of Hsp90 activity in mammalian cells, whereas Ago2-RISCs "pre-loaded" with small RNAs remain highly stable even after Hsp90 inhibition (Johnston et al. 2010). The overall reduction of Siwi- 
and BmAgo3-bound piRNAs as well as their steady-state protein levels (Figs. 1, 2) is consistent with the view that, upon 17AAG treatment, de novo biogenesis of piRNAs was impaired and the resultant RNA-free PIWI proteins were largely degraded, while a preexisting pool of piRNA-RISCs remained stable. A part of the piRNA biogenesis pathway-loading of pre-piRNAs into Siwi, and trimming and $2^{\prime}-O$-methylation of their $3^{\prime}$ ends - can be recapitulated in vitro (Kawaoka et al. 2011). Thus, we examined the effect of Hsp90 inhibition at each of these steps using this system. Since Siwi-bound piRNAs predominantly begin with $U$ in vivo, the $1 \mathrm{U}$ bias is an important indicator of canonical Siwi-RISC assembly in vitro. We performed in vitro pre-piRNA loading assay using lysate from BmN4 cells expressing Flag-Siwi and synthetic 50-nt single-stranded RNAs beginning with $\mathrm{U}, \mathrm{A}, \mathrm{G}$, or $\mathrm{C}$ (1U/1A/1G/1C-50 RNAs) (Fig. 3A). We incubated the lysate with $5^{\prime}-{ }^{32} \mathrm{P}$-radiolabeled $1 \mathrm{U} / 1 \mathrm{~A} / 1 \mathrm{G} / 1 \mathrm{C}-50$ RNAs in the presence or absence of 17-AAG and then immunoprecipitated Flag-Siwi by anti-Flag antibody. The efficiency of FlagSiwi immunoprecipitation was unaffected by 17-AAG (data not shown). Finally, we extracted RNAs and measured the amount of Siwi-bound RNAs. In the absence of 17-AAG,
Siwi preferentially incorporated $1 \mathrm{U}-50$ RNAs, recapitulating canonical pre-piRNA loading (Fig. 3B,C). In the presence of 17-AAG, however, Siwi largely lost the $1 \mathrm{U}$ preference (Fig. 3B,C). Geldanamycin, another Hsp90 inhibitor, showed a similar effect (Supplemental Fig. S4). Thus, Hsp90 is required for Siwi to load pre-piRNAs properly. In contrast, 17-AAG did not affect the $3^{\prime}$-end trimming of Siwi-loaded pre-piRNAs or 2'-O-methylation (Fig. 3D,E). Therefore, Hsp90 is specifically required for accurate pre-piRNA loading into Siwi but not for the subsequent maturation steps (Fig. $3 \mathrm{~F})$. This is consistent with our in vivo observation that the abundance of Siwi-bound piRNAs was reduced without affecting their length (Figs. 1D, 2A,D).

Accumulation of 16-nt RNAs in Ago3 upon 17-AAG treatment (Fig. 1D; Xiol et al. 2012) indicates that Hsp90 functions not only in primary loading of pre-piRNAs into Siwi but also in the ping-pong amplification of secondary piRNAs. In the current model of the piRNA biogenesis, BmAgo3 should not autonomously incorporate single-stranded RNAs, but should rather exclusively receive the cleavage products by Siwi. Unfortunately, there has been no in vitro system that recapitulates such an RNA hand-over mechanism. However,
A

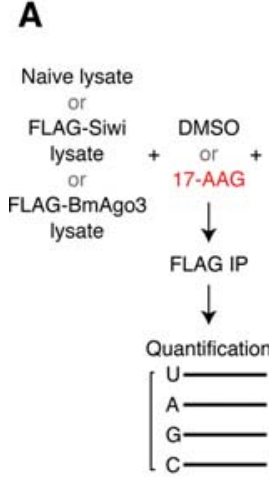

D

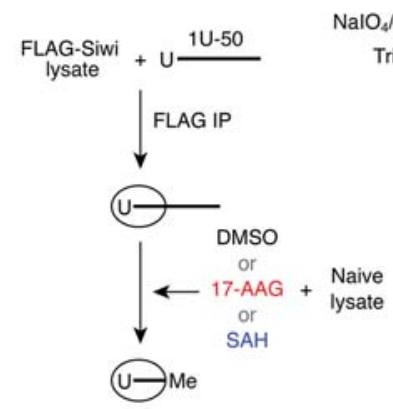

E
B

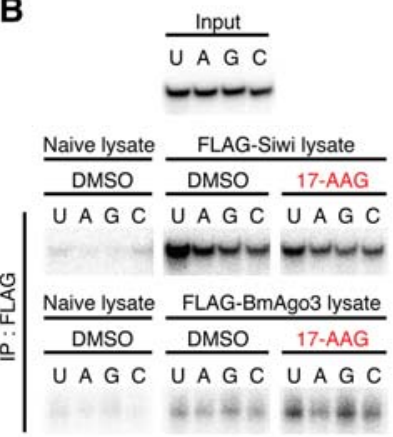

$\mathrm{NaIO}_{4} / \beta$-elimination:

rimming (min):

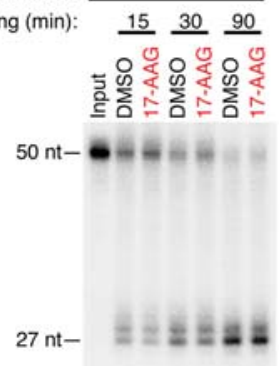

C
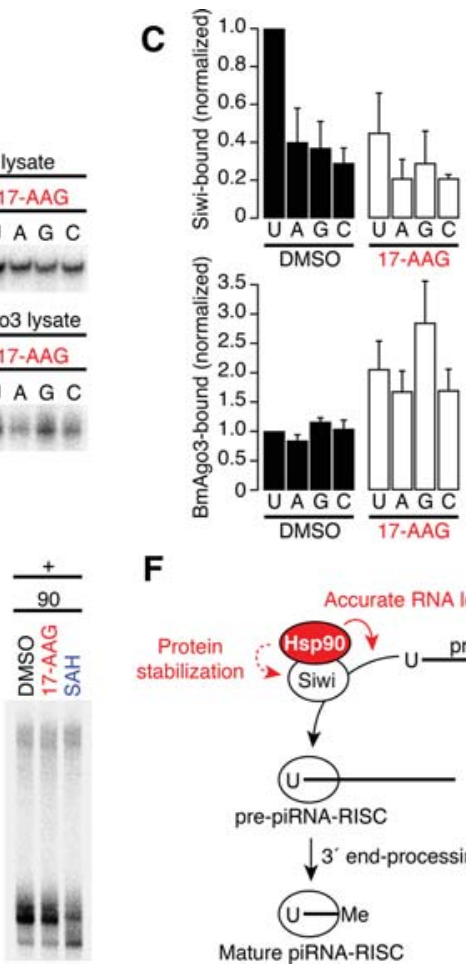

$\mathbf{F}$

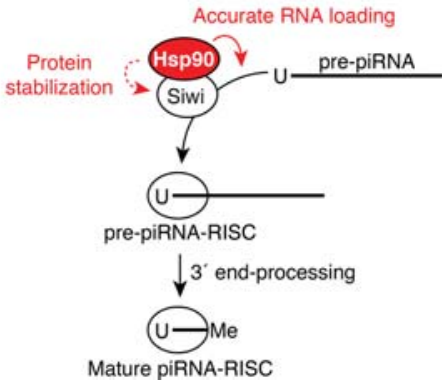

FIGURE 3. Hsp90 facilitates accurate pre-piRNA loading in vitro. (A) Experimental procedure for $B$. (B) Fifty-nucleotide $5^{\prime}$-radiolabeled RNAs with $5^{\prime} \mathrm{U}, \mathrm{A}, \mathrm{G}$, or $\mathrm{C}$ were incubated in lysates prepared from wild-type BmN4 cells (naïve) or Flag-Siwi- or Flag-BmAgo3-expressing cells in the presence or absence of $1 \mathrm{mM}$ 17-AAG. After immunoprecipitation with anti-Flag antibody, Siwi- or BmAgo3-bound RNAs were detected. (C) Quantification for $B$. The level of Siwi- or BmAgo3-bound 1U-50 RNA in DMSO control was normalized to 1 . The average \pm standard deviations from three independent trials are shown. 17-AAG abolished the $1 \mathrm{U}$ preference of Siwi, while promoting promiscuous incorporation into BmAgo3. (D) Experimental procedure for $E$. (E) 1U-50 RNA loaded into Flag-Siwi was subjected to the trimming assay in the presence or absence of $1 \mathrm{mM} 17-\mathrm{AAG}$. The 27- to 28-nt trimming products were generated even in the presence of 17-AAG and were resistant to $\mathrm{NaIO}_{4}$-mediated oxidization followed by $\beta$-elimination, which is indicative of $2^{\prime}$-O-methylation. As a control, addition of $1 \mathrm{mM} \mathrm{S}$-adenosyl homocysteine (SAH) inhibited 2'-O-methylation of the trimming product, which resulted in its faster gel migration after $\mathrm{NaIO}_{4} / \beta$-elimination. $(F)$ A function of $\mathrm{Hsp} 90$ in the primary piRNA pathway. Hsp90 is required for accurate loading of pre-piRNAs into Siwi, but not for subsequent $3^{\prime}$-end trimming and 2'-O-methylation. 
in vitro, BmAgo3 can incorporate 50-nt RNAs to some extent, without showing significant $5^{\prime}$-nucleotide preference (Kawaoka et al. 2011), which likely represents a marginal activity of BmAgo3 to load primary piRNAs. Intriguingly, 17AAG enhanced the overall incorporation of 50-nt RNAs into BmAgo3 (Fig. 3B,C). The loss of the $1 \mathrm{U}$ bias of Siwi and the enhanced overall RNA incorporation of BmAgo3 by $17-\mathrm{AAG}$ treatment in vitro may suggest that $\mathrm{Hsp} 90$ functions to ensure the distinct RNA-loading mechanisms of Siwi and BmAgo3. Supporting this idea, both the $1 \mathrm{U}$ bias of Siwibound piRNAs and the 10A bias of BmAgo3-bound piRNAs were slightly but significantly loosened when $\mathrm{BmN} 4$ cells were treated with 17-AAG (Fig. 2C). Notably, in fly ovaries, depletion of Aubergine, of which Siwi is the silkworm counterpart, caused accumulation of cytoplasmic foci containing unloaded Ago3, Krimper (a Tudor-domain protein), Hsp90, and Shutdown (Malone et al. 2009; Olivieri et al. 2012). Similarly, in the fly ovarian somatic cells, where only the primary processing pathway operates, ectopically expressed fly Ago3 failed to incorporate piRNAs, and such unloaded Ago3 and Shutdown accumulated in Krimperenriched cytoplasmic foci called Krimp bodies (Olivieri et al. 2012). Thus, the Hsp90 chaperone machinery together with Krimper may sequester unloaded Ago3 protein from promiscuously incorporating primary piRNAs by maintaining its proper structure, until Ago3 is docked on the pingpong platform. Further investigation is warranted to address these hypotheses.

\section{MATERIALS AND METHODS}

\section{Cell lines}

$\mathrm{BmN} 4$ cells were cultured at $27^{\circ} \mathrm{C}$ in IPL-41 medium (Applichem) supplemented with $10 \%$ fetal bovine serum.

\section{General methods for in vitro experiments}

Preparation of $40 \times$ reaction mix (containing ATP, ATP regeneration system, and RNase inhibitor), lysis buffer (30 mM HEPES-KOH at $\left.\mathrm{pH} 7.4,100 \mathrm{mM} \mathrm{KOAc}, 2 \mathrm{mM} \mathrm{Mg}(\mathrm{OAc})_{2}\right)$, and $2 \times$ PK buffer has been previously described in detail (Haley et al. 2003).

\section{In vitro assay for piRNA biogenesis}

In vitro pre-piRNA loading, trimming, $\mathrm{NaIO}_{4}$-mediated oxidation, and $\beta$-elimination were performed as described previously (Kawaoka et al. 2011). 17-AAG (Sigma-Aldrich) was used at a final concentration of $1 \mathrm{mM}$.

\section{Western blotting}

Western blotting was performed as described previously with antiFlag (1:1000; Sigma-Aldrich), Actin (1:3000; Santa Cruz), Siwi (1:3000), and BmAgo3 (1:3000) antibodies (Kawaoka et al. 2009).

\section{RNA extraction, reverse transcription, quantitative PCR, and $3^{\prime}$-end labeling}

Total RNAs were extracted by using TRIzol reagent (Invitrogen) or the miRVana miRNA isolation kit (Ambion) according to the manufacturers' instructions. Reverse transcription for mRNAs and the following quantitative PCR analyses were performed essentially as described previously (Kawaoka et al. 2008). The primer sequences for quantitative PCR analyses are listed in Supplemental Table 2. RNA $3^{\prime}$-end labeling was performed with $2 \mu \mathrm{M}\left[\alpha^{-32} \mathrm{P}\right]$ cordycepin $5^{\prime}$-triphosphate (Perkinelmer) and yeast poly(A) polymerase (USB) for $30 \mathrm{~min}$ at $37^{\circ} \mathrm{C}$.

\section{piRNA library construction and bioinformatic analyses}

piRNA libraries were constructed as described previously (Kawaoka et al. 2009). To analyze the change of piRNA abundance by 17-AAG, we used the number of reads matching $5 S$ ribosomal RNA fragments for normalization because they were relatively unsusceptible to 17AAG treatment; miRNAs were unsuitable for normalization purpose, since Hsp90 plays a critical role in their biogenesis (Iwasaki et al. 2010; Johnston et al. 2010). When analyzing the change of the nucleotide composition of Siwi- and BmAgo3-bound piRNAs, the total genome-mapping reads were used for normalization. Bioinformatic analyses were performed with the aid of in-house UNIX and R programs, which will be provided upon request.

\section{DATA DEPOSITION}

The piRNA deep sequencing data used in this study are available under the accession number of DRA000943 (DDBJ).

\section{SUPPLEMENTAL MATERIAL}

Supplemental material is available for this article.

\section{ACKNOWLEDGMENTS}

We thank Hervé Seitz and members of our laboratories for critical comments on the manuscript. This work was supported by a Grant-in-Aid for Scientific Research on Innovative Areas ("Functional Machinery for Non-coding RNAs") to Su.K. and Y.T., and the Program for Promotion of Basic and Applied Researches for Innovations in Bio-oriented Industry to Su.K. Sh.K. and N.I. are recipients of a fellowship from the Japan Society for the Promotion of Science.

Received November 5, 2012; accepted April 8, 2013.

\section{REFERENCES}

Brennecke J, Aravin AA, Stark A, Dus M, Kellis M, Sachidanandam R, Hannon GJ. 2007. Discrete small RNA-generating loci as master regulators of transposon activity in Drosophila. Cell 128: 1089-1103.

Gangaraju VK, Yin H, Weiner MM, Wang J, Huang XA, Lin H. 2011. Drosophila Piwi functions in Hsp90-mediated suppression of phenotypic variation. Nat Genet 43: 153-158.

Ghildiyal M, Zamore PD. 2009. Small silencing RNAs: An expanding universe. Nat Rev Genet 10: 94-108. 
Gunawardane LS, Saito K, Nishida KM, Miyoshi K, Kawamura Y, Nagami T, Siomi H, Siomi MC. 2007. A Slicer-mediated mechanism for repeat-associated siRNA $5^{\prime}$ end formation in Drosophila. Science 315: 1587-1590.

Haley B, Tang G, Zamore PD. 2003. In vitro analysis of RNA interference in Drosophila melanogaster. Methods 30: 330-336.

Horwich MD, Li C, Matranga C, Vagin V, Farley G, Wang P, Zamore PD. 2007. The Drosophila RNA methyltransferase, DmHen1, modifies germline piRNAs and single-stranded siRNAs in RISC. Curr Biol 17: $1265-1272$.

Houwing S, Kamminga LM, Berezikov E, Cronembold D, Girard A, van den Elst H, Filippov DV, Blaser H, Raz E, Moens CB, et al. 2007. A role for Piwi and piRNAs in germ cell maintenance and transposon silencing in zebrafish. Cell 129: 69-82.

Ipsaro JJ, Haase AD, Knott SR, Joshua-Tor L, Hannon GJ. 2012. The structural biochemistry of Zucchini implicates it as a nuclease in piRNA biogenesis. Nature 491: 279-283.

Iwasaki S, Kobayashi M, Yoda M, Sakaguchi Y, Katsuma S, Suzuki T, Tomari Y. 2010. Hsc70/Hsp90 chaperone machinery mediates ATP-dependent RISC loading of small RNA duplexes. Mol Cell 39: 292-299.

Johnston M, Geoffroy MC, Sobala A, Hay R, Hutvagner G. 2010. HSP90 protein stabilizes unloaded Argonaute complexes and microscopic P-bodies in human cells. Mol Biol Cell 21: 1462-1469.

Kamal A, Thao L, Sensintaffar J, Zhang L, Boehm MF, Fritz LC, Burrows FJ. 2003. A high-affinity conformation of Hsp90 confers tumour selectivity on Hsp90 inhibitors. Nature 425: 407-410.

Kawaoka S, Minami K, Katsuma S, Mita K, Shimada T. 2008. Developmentally synchronized expression of two Bombyx mori Piwi subfamily genes, SIWI and BmAGO3 in germ-line cells. Biochem Biophys Res Commun 367: 755-760.

Kawaoka S, Hayashi N, Suzuki Y, Abe H, Sugano S, Tomari Y, Shimada T, Katsuma S. 2009. The Bombyx ovary-derived cell line endogenously expresses PIWI/PIWI-interacting RNA complexes. RNA 15: $1258-1264$.

Kawaoka S, Izumi N, Katsuma S, Tomari Y. 2011. 3' end formation of PIWI-Interacting RNAs in vitro. Mol Cell 43: 1015-1022.

Kawaoka S, Mitsutake H, Kiuchi T, Kobayashi M, Yoshikawa M, Suzuki Y, Sugano S, Shimada T, Kobayashi J, Tomari Y, et al. 2012. A role for transcription from a piRNA cluster in de novo piRNA production. RNA 18: 265-273.

Kirino Y, Mourelatos Z. 2007. Mouse Piwi-interacting RNAs are 2'-Omethylated at their $3^{\prime}$ termini. Nat Struct Mol Biol 14: 347-348.
Klattenhoff C, Theurkauf W. 2008. Biogenesis and germline functions of piRNAs. Development 135: 3-9.

Klattenhoff C, Xi H, Li C, Lee S, Xu J, Khurana JS, Zhang F, Schultz N, Koppetsch BS, Nowosielska A, et al. 2009. The Drosophila HP1 homolog Rhino is required for transposon silencing and piRNA production by dual-strand clusters. Cell 138: 1137-1149.

Malone CD, Hannon GJ. 2009. Small RNAs as guardians of the genome. Cell 136: 656-668.

Malone CD, Brennecke J, Dus M, Stark A, McCombie WR, Sachidanandam R, Hannon GJ. 2009. Specialized piRNA pathways act in germline and somatic tissues of the Drosophila ovary. Cell 137: 522-535.

Muerdter F, Olovnikov I, Molaro A, Rozhkov NV, Czech B, Gordon A, Hannon GJ, Aravin AA. 2012. Production of artificial piRNAs in flies and mice. RNA 18: 42-52.

Nishimasu H, Ishizu $H$, Saito $K$, Fukuhara S, Kamatani MK, Bonnefond L, Matsumoto N, Nishizawa T, Nakanaga K, Aoki J, et al. 2012. Structure and function of Zucchini endoribonuclease in piRNA biogenesis. Nature 491: 284-287.

Ohara T, Sakaguchi Y, Suzuki T, Ueda H, Miyauchi K, Suzuki T. 2007. The $3^{\prime}$ termini of mouse Piwi-interacting RNAs are $2^{\prime}$-O-methylated. Nat Struct Mol Biol 14: 349-350.

Olivieri D, Senti KA, Subramanian S, Sachidanandam R, Brennecke J. 2012. The cochaperone shutdown defines a group of biogenesis factors essential for all piRNA populations in Drosophila. Mol Cell 47: 954-969.

Preall JB, Czech B, Guzzardo PM, Muerdter F, Hannon GJ. 2012. shutdown is a component of the Drosophila piRNA biogenesis machinery. RNA 18: 1446-1457.

Saito K, Sakaguchi Y, Suzuki T, Suzuki T, Siomi H, Siomi MC. 2007. Pimet, the Drosophila homolog of HEN1, mediates 2'-O-methylation of Piwi-interacting RNAs at their $3^{\prime}$ ends. Genes Dev 21: 1603-1608.

Specchia V, Piacentini L, Tritto P, Fanti L, D’Alessandro R, Palumbo G, Pimpinelli S, Bozzetti MP. 2010. Hsp90 prevents phenotypic variation by suppressing the mutagenic activity of transposons. Nature 463: 662-665.

Vagin VV, Sigova A, Li C, Seitz H, Gvozdev V, Zamore PD. 2006. A distinct small RNA pathway silences selfish genetic elements in the germline. Science 313: 320-324.

Xiol J, Cora E, Koglgruber R, Chuma S, Subramanian S, Hosokawa M, Reuter M, Yang Z, Berninger P, Palencia A, et al. 2012. A role for Fkbp6 and the chaperone machinery in piRNA amplification and transposon silencing. Mol Cell 47: 970-979. 
RNA 19: 896-901 (2013)

\title{
Corrigendum: Hsp90 facilitates accurate loading of precursor piRNAs into PIWI proteins
}

\author{
NATSUKO IZUMI, SHINPEI KAWAOKA, SATOSHI YASUHARA, YUTAKA SUZUKI, SUMIO SUGANO, \\ SUSUMU KATSUMA, and YUKIHIDE TOMARI
}

The authors noticed that there were errors in the primer sequences in Supplemental Table 2 of the above-noted article. Reverse complementary sequences were given for the Pao, L1Bm, R1Bm, R2Bm, SART1, Bmmar6, and Kabuki reverse primers, and the forward and reverse primers were switched for the $\mathrm{L1Bm}$ and $\mathrm{R} 2 \mathrm{Bm}$ primer sets. Moreover, an additional TGA sequence was inserted in the $L 1 \mathrm{Bm}$ reverse primer. These errors occurred when the sequences were manually input into a data-management software used in the laboratory. The corrected Supplemental Table 2 is now available online (Revised_Supplemental_Table_2. docx).

The correct sequences of these primers have been confirmed by the labels on the original tubes and/or the original order receipts (available at http://www.iam.u-tokyo.ac.jp/tomari/rna2013corrigendum.pdf). The errors do not affect the conclusions of the paper, and the authors apologize for any confusion this may have caused.

doi: $10.1261 /$ rna.052308.115 

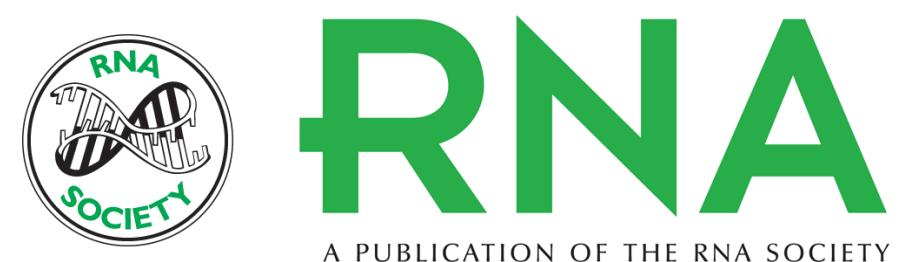

A PUBLICATION OF THE RNA SOCIETY

\section{Hsp90 facilitates accurate loading of precursor piRNAs into PIWI proteins}

Natsuko Izumi, Shinpei Kawaoka, Satoshi Yasuhara, et al.

RNA 2013 19: 896-901 originally published online May 16, 2013

Access the most recent version at doi:10.1261/rna.037200.112

\section{Supplemental http://rnajournal.cshlp.org/content/suppl/2013/04/24/rna.037200.112.DC1 \\ Material http://rnajournal.cshlp.org/content/suppl/2015/04/01/rna.037200.112.DC2}

Related Content Corrigendum: Hsp90 facilitates accurate loading of precursor piRNAs into PIWI proteins

Natsuko Izumi, Shinpei Kawaoka, Satoshi Yasuhara, et al.

RNA June, 2015 21: 1217

References This article cites 29 articles, 9 of which can be accessed free at: http://rnajournal.cshlp.org/content/19/7/896.full.html\#ref-list-1

Articles cited in:

http://rnajournal.cshlp.org/content/19/7/896.full.html\#related-urls

Creative This article is distributed exclusively by the RNA Society for the first 12 months after the Commons full-issue publication date (see http://rnajournal.cshlp.org/site/misc/terms.xhtml). After 12

License months, it is available under a Creative Commons License (Attribution-NonCommercial 3.0 Unported), as described at http://creativecommons.org/licenses/by-nc/3.0/.

Email Alerting
Service

Receive free email alerts when new articles cite this article - sign up in the box at the top right corner of the article or click here.

To subscribe to RNA go to:

http://rnajournal.cshlp.org/subscriptions 